Ks. dr hab. Marek Kluz, prof. UPJPII

Uniwersytet Papieski Jana Pawła II w Krakowie

Ks. dr Józef Młyński

Uniwersytet Kardynała Stefana Wyszyńskiego w Warszawie

\title{
Budowanie społeczeństwa jako rodziny ludzkiej w nauczaniu Jerzego Bajdy
}

\section{Wstęp}

W socjologii społeczeństwo bywa rozumiane jako zbiorowość lub duża grupa społeczna połączona terytorialnie, geograficznie i kulturowo. Stąd też jawi się jako najbardziej złożona zbiorowość społeczna na którą składają się obiektywne warunki bytu, czyli przyroda, ekonomia oraz kultura i struktura społeczna. Dlatego też August Comte i Herbert Spencer definiowali społeczeństwo jako całość składającą się z wzajemnie zależnych od siebie elementów, dzięki którym możliwe jest funkcjonowanie i rozwój całej zbiorowości.

Społeczeństwo nie jest jednak tworem samym w sobie, jest spójnością działań osób i innych jego podmiotów. Do właściwego funkcjonowania $\mathrm{w}$ przestrzeni społecznej potrzebuje innych ludzi oraz dobrze funkcjonujących instytucji. Tomasz
- Wstęp

- Społeczeństwo: tajemnica rodziny i człowieka

- Zadania rodziny wobec rzeczywistości ziemskich

- Zadania wspólnoty ludzkiej w zakresie życia społecznoekonomicznego - Stworzenie prawnej przestrzeni dla rozwoju rodziny w społeczeństwie obywatelskim

- Zakończenie 
Merton pisał: „nikt nie jest samotną wyspą”"1. Dlatego też jednostka realizująca w środowisku społecznym subiektywne i obiektywne cele, tworzy rodzinę $\mathrm{w}$ sensie biologicznym i społecznym; rodzina jest instytucją i grupą społeczną.

Rodzina zatem jest nie tylko środowiskiem kształtowania osobowości, ale również istotnym ogniwem budowania życia. Warto zatem zwrócić uwagę, że oprócz nauki dzieci praktycznych umiejętności, które umożliwią im życie, ważne jest również wychowanie chrześcijańskie do życia w społeczeństwie.

Ukazanie społeczeństwa jako wspólnoty osób wydaje się bardzo ważne. Problem ten zauważył Jerzy Bajda, dla którego

Ojczyzna to wspólnotowy obowiązek. Ojczyzna [...] może istnieć jedynie jako organizm społeczny na nowo budowany i nieustannie tworzony wysiłkiem moralnym skierowanym ku doskonaleniu człowieka i wspólnoty na wszystkich poziomach zjednoczenia ${ }^{2}$.

W związku z tym warto zastanowić się nad relacją, jaka istnieje między rodziną i innymi wspólnotami ziemskimi, których jest ona niezastąpioną częścią. Warto pochylić się również nad całością relacji zachodzących między rodziną, państwem i wspólnotą Kościoła.

\section{Społeczeństwo: tajemnica rodziny i człowieka}

Zarówno Konstytucja duszpasterska o Kościele w świecie współczesnym, jak i Konstytucja dogmatyczna o Kościele mówią o potrzebie przebudowy społeczeństwa w taki sposób, by ujawniło ono prawdę o sobie jako „rodzinie dzieci Bożych”3. Nie chodzi jednak o proste stwierdzenie, że ludzkość jest sumą rodzin, ale o ukazanie istotnych rysów ujawniających prawdę o tej rodzinnej wspólnocie. Jest to możliwe tylko przy urzeczywistnieniu jej dwóch filarów: pełnego powołania każdej osoby oraz braterskiej solidarności wyrażającej się we wzajemnym wspomaganiu i rozwoju ${ }^{4}$.

1 T. Merton, Nikt nie jest samotna wyspq, Warszawa 2008, s. 3.

2 J. Bajda, Odpowiedzialność za Polskę, "Nasz Dziennik" (2001) nr 5, s. 7.

3 Por. Konstytucja duszpasterska o Kościele w świecie współczesnym Gaudium et spes, nr 50 [dalej: GS].

4 Por. Paweł VI, Enc. Populorum progressio [dalej: PP] , nr 14-18. 
Głównym przejawem choroby ludzkości nie są problemy ekonomiczne, ale rozluźnienie braterskich więzi między ludźmi, jak i między naroda$\mathrm{mi}^{5}$. Rodzi to konieczność stworzenia wspólnoty, która byłaby prawdziwie godna ludzi ${ }^{6}$. Takie idealne społeczeństwo nie jest utopią. Jest ono możliwe, ale konieczna do jego osiągnięcia jest Boża energia przenikająca ludzkość 7 .

Chrześcijanin ożywiony mocą Chrystusowego Ducha, umocniony nadzieją, uczestniczy w budowaniu sprawiedliwego i braterskiego społeczeństwa, będącego miłym darem dla Boga ${ }^{8}$. Powszechne braterstwo umożliwia potrzebę budowania ludzkości jako wspólnoty osób, gdzie nie do przyjęcia jest prawo silniejszego. Społeczeństwo musi ciągle czynić starania, by zasadą postępowania jego członków była miłość ${ }^{9}$. Jednocześnie trzeba pamiętać o współodpowiedzialności każdego człowieka za dobro wspólne ${ }^{10}$. Taka wspólnotowa konstytucja jest konieczna nie tylko ze względu na potrzebę zachowania moralnej tożsamości ludzkiego społeczeństwa, ale też dla jego ocalenia w ogóle ${ }^{11}$. Porzucenie zasad moralnych grozi popadnięciem $w$ niewolę anonimowych dyktatur opartych na przemocy i nienawiści, próbujących sterować całością ludzkiego życia, unicestwiając wolność osoby ${ }^{12}$. Człowieka jako podmiotu społeczeństwa bowiem nie można kształtować jedynie według zasad ogólnospołecznych. Trzeba dodać, iż wspólnota ludzka objawia się samej sobie za pośrednictwem odpowiedniej duchowej symboliki, która stanowi właściwy język dialogu między ludźmi. Odczytanie tej symboliki decyduje o poziomie i charakterze całego dialogu, poprzez który dokonuje się nie tylko wymiana wartości duchowych, ale również moralna identyfikacja ludzkiej wspólnoty. Mowa tu o symbolach uniwersalnych, w których ludzkość odczytuje sens swego życia i przeznaczenie ${ }^{13}$.

Samo poznanie empiryczno-racjonalne nie daje człowiekowi możliwości dotarcia do prawdy. Poznaniem właściwym człowiekowi jest kontemplacja mądrości ${ }^{14}$. Intelektualna natura osoby ludzkiej udoskonala się przez mądrość,

5 Por. PP 66.

6 Por. PP 54.

7 Por. J. Bajda, Powołanie małżeństwa..., s. 137.

8 Por. Benedykt XVI, Enc. Spe salvi, nr 32.

9 Por. J. Bajda, Powołanie do rodziny. Podstawy teologiczno-moralne, w: Wychowanie do miłości, red. K. Majdański, Warszawa 1987, s. 34-47.

10 Por. Franciszek, Enc. Lumen fidei, nr 51.

11 Por. J. Bajda, Powołanie małżeństwa..., dz. cyt., s. 137.

12 Por. Jan Paweł II, Enc. Centesimus annus, nr 46.

13 Por. J. Bajda, Powołanie małżeństwa..., dz. cyt., s. 138.

14 Por. J. Bajda, Powołanie małżeństwa..., dz. cyt., s. 138. 
która pociąga umysł człowieka do umiłowania tego, co dobre i prawdziwe. Przepojony nią człowiek przez rozpoznanie rzeczy widzialnych dochodzi do tych, które nie mogą być rozpoznane za pomocą zmysłów. Nasza epoka, bardziej niż minione, potrzebuje takiej mądrości, która wszystkie nowe rzeczy, które stają na drodze człowieka, uczyniła bardziej ludzkimi ${ }^{15}$. Jest to zatem budowanie społeczeństwa na wzór rodziny jako wspólnoty życia i miłości.

Istnieje jednak potrzeba wykształcenia nowego humanizmu, opartego na absolutnie bezinteresownych wartościach, jak miłość, przyjaźń, modlitwa i kontemplacja. Tylko taki humanizm może stać się podstawą pełnego rozwoju człowieka i społeczeństwa. Brak takiego obrazu sprawia, że niemożliwe jest właściwe rozwiązanie problemów społecznych, szczególnie demograficznych ${ }^{16}$.

Człowiek jest tajemnicą, dlatego dopiero w Bożym świetle staje się w pełni zrozumiały ${ }^{17}$. Zamykając się w horyzoncie prawdy empiryczno-racjonalnej ludzkość wpada w pewnego rodzaju pułapkę. Opanowawszy przyrodę za pomocą światła rozumu, człowiek znalazł się w „kleszczach” własnego rozumowania i sam staje się przedmiotem nauki, co powoduje jego redukcję i okalecza jego człowieczeństwo ${ }^{18}$; tego rodzaju redukcja człowieka prowadzi do dehumanizacji.

Okaleczenie człowieka i humanizmu polega przede wszystkim na zatraceniu poczucia tajemnicy, a w konsekwencji niezdolności do odczytania ludzkiej natury jako symbolu. Jedynie symbol jest właściwym językiem umożliwiającym wejście człowieka w relację z tajemnicą. Możliwość odczytania ludzkiej natury jako symbolu polega na kreacjonistycznej interpretacji ludzkiego bytu uformowanego w swego rodzaju materialno-duchowej jedności ${ }^{19}$. Podobnie jak nie można oddzielić rodziny od społeczeństwa, nie powinno się również oddzielać jednostki od społeczeństwa. Społeczeństwo jest bowiem zbiorowością i wspólnotą, której fundament i tożsamość stanowi tajemnica człowieka jej.

Jeśli, jak to wynika z wcześniejszych analiz, duchową treścią społecznego dialogu jest tajemnica człowieka i rodziny, to dialog może zaistnieć tylko

\footnotetext{
15 Por. GS 15.

16 Por. HV 7.

17 Por. Jan Paweł II, Enc. Redemptor hominis, nr 7.

18 Por. J. Bajda, Powołanie małżeństwa..., dz. cyt., s. 139.

19 Por. GS 2.
} 
wtedy, gdy zostaną ocalone podstawowe symbole, wyrażające głębszy sens ludzkiej egzystencji. Istotą symbolu jest uduchowienie materialnej rzeczywistości, co sprawia, że staje się ona wewnętrznym darem osobowej i wspólnotowej relacji. Elementarnym pojęciem jest życie konkretnego człowieka. To właśnie ono może się stać objawieniem tajemnicy obecności, odczytywanym jako słowo i dar. Symbolem w pełnym znaczeniu może stać się życie osobowe, uformowane bezpośrednio przez element duchowy, i przez to objawiające swą wewnętrzną jedność i tożsamość podmiotu niepodzielnego w swym akcie samoobjawienia i objawianej treści. Tym sposobem obecność życia istoty ludzkiej jest aktem prawdziwego „zaistnienia” człowieka, czyli symbolem człowieka. Jest to objawienie prawdy, której nie można objąć za pomocą zmysłów. Prawdę samoobjawienia osoby można pojąć jedynie przez kontemplację tajemnicy, możliwą dzięki symbolowi, a nie za pośrednictwem prostej syntezy poznania zmysłowo-racjonalnego ${ }^{20}$.

Wynika zatem, iż społeczeństwo określane jako tajemnica rodziny i człowieka jest dobrem wspólnym. Rodzina zaś jest „podstawową komórką życia społecznego. Jest naturalną społecznością, w której mężczyzna i kobieta są wezwani do daru z siebie w miłości i do przekazywania życia. Autorytet, stałość i życie w związkach rodzinnych stanowią podstawy wolności, bezpieczeństwa i braterstwa w społeczeństwie"21.

\section{Zadania rodziny wobec rzeczywistości ziemskich}

Współczesna rodzina ulega wpływom rozległych przemian społecznych i kulturowych. Wiele rodzin przeżywa ten stan rzeczy, dochowując wierności wartościom stanowiącym fundament instytucji rodziny. Inne niestety są zagubione wobec tych wyzwań, a niekiedy nawet tracą świadomość ostatecznego znaczenia i prawdy życia małżeńskiego i rodzinnego. Jeszcze inne spotykają się z przeszkodami w korzystaniu z przysługujących im praw ${ }^{22}$.

Wspólnota Kościoła jest zainteresowana rzeczywistością rodziny, ponieważ według myśli Bożej Kościół ma być jednością. Bóg chce, by wszyscy ludzie tworzyli jedną rodzinę i odnosili się do siebie w duchu braterstwa. „On

20 Por. Powołanie małżeństwa..., dz. cyt., s. 140.

21 Katechizm Kościoła katolickiego, nr 2207.

22 Por. Jan Paweł II, Adhort. Familiaris consortio, nr 1 [dalej: FC]. 
z jednego [człowieka] wywiódł cały rodzaj ludzki, aby zamieszkiwał całą powierzchnię ziemi. Określił właściwe czasy i granice zamieszkania” (Dz 17, 26).

Jeżeli ludzkość ma się stać jedną rodziną, to znaczy, że powołanie człowieka posiada istotne rysy rodzinne. Pełnia powołania zatem powinna być osiągnięta w istotnej relacji do rodziny, która jest źródłem, formą i szczytem powołania wspólnotowego ludzkości. Rodzina jest istotnym elementem konstytucji Kościoła. Charakterystyczne jest to, że obydwie te formy jedności, odznaczające się pełnią i autentycznością, są sakramentalne. Wskazuje to na fakt, że jedność ludzi jest darem samego Boga. Bóg swoim wcieleniem uświęca korzenie ludzkiego istnienia: rodzinę, miłość i ciało ludzkie. Instytucja małżeństwa nastawiona jest na rodzenie i wychowanie potomstwa. Rodzina powinna więc być płodna, bo małżonkowie wyrażają miłość Boga-Stwórcy ${ }^{23}$. Misja Kościoła osiąga swoją syntezę właśnie w rodzinie, która bywa nazywana małym Kościołem ${ }^{24}$. Rodzina ze swej istoty jest rzeczywistością zarówno wewnątrzświatową, jak i wewnątrzkościelną ${ }^{25}$.

Tylko rodzina jest w pełnym znaczeniu źródłem ludzkiego społeczeństwa. Należy do rzeczywistości najwyżej cenionych przez swoje odniesienie do Boskiego źródła. W niej rodzą się nowi obywatele ludzkiej społeczności, którzy przez łaskę chrztu św. stają się synami Bożymi ${ }^{26}$. Rodzina ma za zadanie poprzez swoją obecność w świecie, uświęcać go mocą tajemnicy Chrystusa, z której czerpie siły do życia i którą promieniuje ${ }^{27}$.

Małżeństwo jako sakrament jest powszechnym powołaniem, które przez wieki zapewnia ciągłość istnienia społeczeństwa i ludu Bożego. Według Soboru Watykańskiego II rodzina jest niejako domowym Kościołem ${ }^{28}$, a czasem nawet domowym sanktuarium Kościoła ${ }^{29}$. Dzięki temu dana jej łaska spływa również na cały świat ${ }^{30}$. Rodzina realizuje ponadto trzy podstawowe funkcje Kościoła, tj. prorocką, kapłańską i królewską. Sprawia to, że zajmuje ona bardzo ważne miejsce w dziele ewangelizacji współczesnego świata.

23 Por. J. Bajda, Powołanie małżeństwa..., dz. cyt., s. 132-133.

24 Por. J. Kelly, Złote usta. Jan Chryzostom - asceta, kaznodzieja, biskup, Bydgoszcz 2001, s. 350.

25 Por. Bajda Jerzy, Powołanie małżeństwa..., dz. cyt., s. 133.

26 Por. GS 11.

27 Por. Sobór Watykański II, Konstytucja dogmatyczna o Kościele Lument gentium, nr 31 [dalej: LG].

28 Por. LG 11.

29 Por. Sobór Watykański II, Dekret o apostolstwie świeckich Apostolicam actuositatem, nr 11.

30 Por. Bajda Jerzy, Powołanie małżeństwa..., dz. cyt., s. 133. 
Łaska sakramentu małżeństwa przenikająca życie rodziny winna rozlewać się na innych za pośrednictwem nawiązywanych przez nią więzi społecznych ${ }^{31}$.

Pełnia chrześcijańskiego życia w świecie jest w rzeczywistości moralną eksplikacją łaski, która łaski, która wynika z sakramentu małżeństwa. Małżonkowie muszą czynić starania, by kształtować swe życie według wskazań Ewangelii, współpracować po bratersku dla dobra całej rodziny ludzkiej, która wezwana jest w Chrystusie do rodziny dzieci Bożych. Skoro Bóg-Ojciec jest początkiem i celem wszystkich ludzi, to każdy powołany jest do braterstwa z innymi. Na podstawie tego powołania mamy współpracować ze sobą w budowaniu świata. Bóg chce, byśmy w każdym człowieku widzieli swego brata, miłowali go słowem i czynem, a także dawali świadectwo prawdzie, przekazując innym tajemnicę miłości Ojca niebieskiego ${ }^{32}$.

Powołanie Boże kieruje ludzi do takiego modelu życia, w którym Bóg sam jest doskonale ukazany. Rodzina jest jednocześnie ukoronowaniem Ewangelii, jest równocześnie ukoronowaniem tajemnicy stworzenia, jak i eschatologicznym uobecnieniem tajemnicy Bożego obrazu, ukrytego w rodzicielskiej jedności człowieka. Urzeczywistniona w Chrystusie jedność ciała jest najwyższą i ostateczną formą jedności, dlatego nie wymaga żadnego dopełnienia, lecz wymaga jedynie swego objawienia w historii przez sakramentalny udział ludzkości w tej komunii, jaka zaistniała w Najświętszej Rodzinie ${ }^{33}$.

Rodzina jest właściwym uspołecznieniem człowieka. Jest miejscem otwartym na inne wspólnoty, w których rodzą się energie zdolne do tworzenia więzi życia społecznego i przemieniania świata we wspólnotę braterską ${ }^{34}$.

Źródłem tego uspołecznienia jest istota więzi małżeńskiej, mająca swój początek w akcie stwórczym. Zanim małżeństwo stało się ważną wspólnotą naturalną, było (i nadal jest) ważną rzeczywistością ziemską. Dwoistość płci jest faktem ustanowionym przez Boga, by mężczyzna razem z kobietą byli obrazem Boga i jak On sam stawali się przekazicielem życia: „Bądźcie płodni i rozmnażajcie się, abyście zaludnili ziemię i uczynili ją sobie poddaną"(Rdz 1,28). Jasno przeto widać, że jedność rodzicielska jest źródłem wszelkich form więzi społecznych ${ }^{35}$.

31 Por. Sacramentum matrimonii, „Chrześcijanin w Świecie” nr 40 (1976) 2, s. 105.

32 Por. GS 92-93.

33 Por. J. Bajda, Powołanie małżeństwa..., dz. cyt., s. 134.

34 Por. FC 64.

35 Por. J. Bajda, Powołanie małżeństwa..., dz. cyt., s. 135. 
Rodzina jest ogniwem łączącym bezpośrednio Kościół i świat, zaś ogniwem łączącym rodzinę z całą rzeczywistością świata jest osoba ludzka. Miejscem człowieka jest rodzina, ale jednocześnie życie ludzkie głęboko zakorzenione jest w całej rzeczywistości stworzonego świata. Konsekwentnie człowiek jest tajemnicą świata, jak Chrystus - tajemnicą stworzenia.

Panowanie nad światem i budowanie społecznego ładu jest ściśle podporządkowane tajemnicy ludzkiego życia, objawiającej się w rodzinie niosącej $\mathrm{w}$ sobie transcendentne powołanie Boże ${ }^{36}$. Związek rodziny z rzeczywistością świata polega nie tylko na tym, że rodzina jest główną i podstawową rzeczywistością świata. Rodzina jest także główną zasadą interpretacji relacji człowiek - świat. Interpretacja ta obejmuje zarówno ludzką egzystencję, jak i całą materialną rzeczywistość. Rodzina jest konkretnym wcieleniem Ewangelii i wyznacza kierunek powołania całej ludzkiej społeczności ${ }^{37}$.

\section{Zadania wspólnoty ludzkiej w dziedzinie życia społeczno- ekonomicznego}

Każdy, kto ma wpływ na społeczeństwo, powinien przyczyniać się do skutecznego podnoszenia rangi instytucji małżeństwa i rodziny ${ }^{38}$. Państwo powinno uznawać ich prawdziwą naturę, bronić ich oraz, popierając i strzegąc moralności publicznej, sprzyjać dobrobytowi rodzin. Trzeba bronić prawa rodziców do rodzenia dzieci oraz wychowywania ich w rodzinnie ${ }^{39}$.

Mimo powszechnie uznawanego poglądu, że należy podejmować wszelkie możliwe kroki w celu ograniczenia przyrostu naturalnego na świecie lub przynajmniej w niektórych państwach, Kościół upomina, by wystrzegać się tych rozwiązań publicznie lub prywatnie zalecanych, a czasem nawet narzucanych, które są sprzeczne z prawem naturalnym. Każdy człowiek ma bezdyskusyjne prawo do małżeństwa i zrodzenia dzieci, zaś a liczba potomstwa zależy od etycznie uzasadnionej decyzji rodziców i nigdy nie może być dyktowana przez władzę publiczną ${ }^{40}$.

36 Por. J. Bajda, Rozmyślanie nad "Listem do Efezjan” (5, 28-33) , „Ethos” 43 (1998) nr 3, s. 69.

37 Por. J. Bajda, Powołanie małżeństwa..., dz. cyt., s. 136.

38 Por. J. Wysocki, Rytuat rodzinny, Olsztyn 1981, s. 14.

39 Por. GS 52.

40 Por. GS 87. 
Istota problemu polega więc na sposobie ochrony ludzkiego życia oraz etycznego charakteru przekazywania go przed roszczeniami władzy państwowej usiłującej dysponować życiem człowieka. W niektórych państwach już próbuje się sterować płodnością, pomijając całkowicie związek zachodzący między rodzicielstwem a powołaniem małżeństwa i rodziny. To sterowanie płodnością w najmniejszym stopniu nie rozwiązuje kwestii demograficznej, ale przede wszystkim niszczy wolność człowieka jako podmiotu życia i rodzicielstwa. Skutkuje to pozbawieniem ludzkiego życia jego zasadniczego sensu, ograniczając go do faktu konsumpcyjno-wegetatywnego ${ }^{41}$.

Wielką kartą obrony życia stała się encyklika Humanae vitae papieża Pawła VI. Dokument jasno ukazuje etyczny profil powołania rodzicielskiego oraz wszystkie praktyczne wnioski z zasad ustalonych przez Sobór Watykański II. Warto przypomnieć, do nieetycznych sposobów rozwiązywania problemu demograficznego należą wszelkie formy antykoncepcji, będącej zaprzeczeniem istoty miłości i rodzicielstwa. Zagadnienie to musi być rozpatrywane w kontekście stworzenia, czyli Bożego planu wobec człowieka. Tylko w tej perspektywie możliwe jest rozwiązanie kwestii demograficznej oraz wszystkich innych kwestii społecznych. Obrona świętości małżeństwa jest jednocześnie obroną ludzkiej obyczajowości ${ }^{42}$.

Antykoncepcja pozbawia małżeństwo jego etycznej struktury, wpędzając je w moralną pustkę. W konsekwencji człowiek, nie chcąc być w dziedzinie prokreacji sługą Boga, staje się niewolnikiem ${ }^{43}$. Obowiązek obrony świętości ludzkiego życia wymaga od władz państwowych respektowania praw moralnych wpisanych w życie rodziny. Państwo ma również obowiązek tworzenia odpowiedniego ustawodawstwa, sprzyjającego rozwojowi rodzin oraz dobremu wychowaniu narodów, by zachowywane były zarówno prawo moralne, jak i wolność obywatelska.

Posłannictwo rodziny nigdy nie może być ograniczone wyłącznie do płaszczyzny czysto moralnej ${ }^{44}$. Nie można również oddzielać kwestii demograficznej od postępu. Problematyka demografii jest następstwem i objawem zafałszowania ludzkiego rozwoju w sensie ścisłym. Prawdziwy rozwój społeczny

41 Por. J. Bajda, Powołanie małżeństwa..., dz. cyt., s. 146.

42 Por. Paweł VI, Enc. Humanae vitae, nr 17.

43 Por. J. Bajda, Etyczny ład małżeństwa w świetle encykliki "Humanae vitae”, "Chrześcijanin w Świecie" 86 (1980), s. 77-96.

44 Por. Paweł VI, Enc. Populorum progressio, nr 37. 
wymaga osobistego, ale i wspólnotowego dążenia ludzkości ku pełni człowieczeństwa. Nie można winić Opatrzności za błąd, który leży po stronie ludzi. W poszukiwaniu szczęścia nie wolno zagubić samego człowieka ${ }^{45}$.

Wzrost ekonomiczny jest słuszny i prawdziwy tylko wówczas, gdy pomaga całej społeczności wznosić się ponad uwarunkowania wynikające $\mathrm{z}$ natury i materialne, nie dopuszczając, by ludzie się w nich pogrążyli. Tylko głębokie nawrócenie ducha i serca pozwala na autentyczną naprawę ekonomii ${ }^{46}$.

Naprawa świata w jakiejkolwiek dziedzinie wymaga najpierw wewnętrznej przemiany samego człowieka ${ }^{47}$.

\section{Stworzenie prawnej przestrzeni do rozwoju rodziny w społeczeństwie obywatelskim}

Głównym zadaniem w tym wymiarze jest zlikwidowanie tych zagrożeń i ograniczeń prawnych, które paraliżują rozwój życia w ramach rodziny. Pierwszym zadaniem jest zagwarantowanie pokoju, gdyż jego brak powoduje bezpośrednie zagrożenie życia, więc i rodziny. Wewnętrzna relacja między pokojem i życiem ma swój początek w Boskim źródle obydwu tych wartości. Dodatkowo fakt, że życie jest darem Boga, stanowi o jego świętości. Natomiast skuteczna obrona pokoju zależy w dużej mierze od obrony życia i jego godności. Życie stanowi szczytową wartość pokoju. Nie sposób również nie dopowiedzieć, że wszystkie przesłanki dowodzą, iż rodzina jest szczytem życia. Życia należy bronić, by mógł panować pokój. Trzeba również bronić pokoju, aby ochronić rodzinę, która stanowi właściwe środowisko ludzkiego życia ${ }^{48}$.

Obrona życia implikuje automatycznie obronę podstawowych praw człowieka $^{49}$. Powszechna Deklaracja Praw Człowieka (PDPC) w art. 16 gwarantuje każdemu dorosłemu człowiekowi prawo do zawarcia małżeństwa oraz założenia rodziny, zwracając równocześnie uwagę na jednakowe prawa mężczyzny i kobiety w tym zakresie ${ }^{50}$.

45 Por. HV 23.

46 Por. Jan Paweł II, Enc. Centesimus annus, nr 31.

47 Por. Jan Paweł II, Enc. Dominum et Vivificantem, nr 56.

48 Por. J. Bajda, Powołanie małżeństwa..., dz. cyt., s. 150.

49 Por. GS 27.

50 Por. Powszechna Deklaracja Praw Człowieka, art. 16. 
Prawa te zinterpretowano w sposób zbyt indywidualistyczny, omijając rzeczywiste różnice stanowiące o nierówności sytuacji kobiety i mężczyzny, na przykład w przypadku rozbicia małżeństwa. PDPC gwarantuje jedynie prawa materialno-ekonomiczne, nie biorąc pod uwagę duchowych praw małżeństwa jako całości oraz kobiety i mężczyzny z osobna. Nie zwraca również uwagi na potrzebę trwania nieprzerwanej więzi miłości oraz prawa dziecka do narodzenia się w trwałym i uświęconym środowisku miłości ${ }^{51}$.

Deklaracja nie wskazuje również odpowiedniego zakresu opieki należnej rodzinie, co nadal stawia pod znakiem zapytania respektowanie wszystkich praw rodziny ${ }^{52}$. Nauka Kościoła zawsze podkreśla, że rodzina jest fundamentem społeczeństwa ${ }^{53}$. Natomiast PDPC ogranicza jej rolę wyłącznie do „fundamentalnego elementu”, poważnie redukując tym samym sens zawierający się w pojęciu „fundamentu”. Jeżeli coś nie jest fundamentem, ale tylko elementem składowym, to zawsze istnieje możliwość zastąpienia jednego elementu przez drugi, na przykład pod względem użyteczności, wygody, funkcjonalności lub innych tego typu kryteriów ${ }^{54}$.

Schematy prawne, w których ujęte zostało zagadnienie praw człowieka, zacieśniają definicję człowieka do indywiduum istniejącego w znaczeniu faktyczno-statycznym. Wynika to z zawężenia definicji życia do fizyczno-społecznego stanu konsumpcji i wegetacji. W definicji tej pominięto istotny wymiar ludzkiego życia, czyli sens zrodzenia, którego istota polega na tym, że człowiek jest istotą rodzącą, a zarazem zrodzoną. Stąd też życie ludzkie obejmuje $\mathrm{w}$ sobie istotę zrodzenia i równocześnie stan bycia rodzonym. Zrodzenie jest zaproszeniem, przywoływaniem do wspólnoty rodzinnej mocą miłości rodzicielskiej. Pełna definicja człowieka jako podmiotu ludzkich praw nie może nie uwzględniać tych dwóch wymiarów. Do poprawnej wizji ludzkiego życia potrzebna jest również definicja pełni ludzkich praw, tak by osoba ludzka miała zagwarantowane samo-urzeczywistnianie się we wszystkich wymiarach swej egzystencji ${ }^{55}$. Prawo do życia musi zawierać w sobie wyraźną afirmację prawa do narodzin oraz urzeczywistnienia małżeństwa jako autentycznej wspólnoty

51 Por. J. Bajda, Powołanie małżeństwa..., dz. cyt., s. 150.

52 Por. Powszechna Deklaracja Praw Człowieka, art. 16.

53 Por. GS nr 52.

54 Por. J. Bajda, Powołanie małżeństwa..., dz. cyt., s. 151.

55 Por. J. Bajda, Powołanie małżeństwa..., dz. cyt., s. 151. 
miłości, w której rodzice realizują swoją misję zrodzenia i wychowania potomstwa ${ }^{56}$.

Praw ludzkich nie można rozpatrywać wyłącznie w perspektywie doczesnej, konsumpcyjnej. U źródeł wszystkich ludzkich praw stoi tajemnica Boga objawiającego się jako wcielona miłość. W konsekwencji pogwałcenie ludzkich praw jest równocześnie pogwałceniem tej najwyższej miłości ${ }^{57}$. Prawa ludzkie mogą być prawdziwie respektowane tylko w perspektywie najwyższego powołania ludzkiego. Analogicznie wygląda sprawa wspólnoty rodzinnej. Rodzina musi być uznana za transcendentną formę ludzkiego życia ${ }^{58}$.

Warto w tym miejscu zwrócić uwagę na jedną z form dyskryminacji kobiety, wynikającą z określonej koncepcji społeczeństwa. Kultura oparta na tej nierówności często bywa nazywana cywilizacją „męską", ponieważ przyznaje prymat zasadzie siły i panowania oraz faworyzuje politykę, ekonomię i konsumpcjonizm interpretowany jako zaspokajanie potrzeb mężczyzny jako organizatora życia społecznego. Skutkiem tej dyskryminacji jest powstanie ruchów i stowarzyszeń głoszących potrzebę równouprawnienia kobiet. Niestety w zdecydowanej większości organizacje te przyjęly fałszywą formę, stawiając za cel sobie maskulinizację kobiet ${ }^{59}$.

W celu uzdrowienia relacji między mężczyzną i kobietą należy przyjąć zasadę komplementarności, respektującą właściwy kobiecie wkład w budowę społeczeństwa ${ }^{60}$. Kryzys społeczny jest ściśle powiązany z błędnym pojmowaniem powołania kobiety. Konieczna jest obrona praw kobiet oraz odbudowa zdrowego klimatu społeczno-moralnego, by podnieść rolę, jaką kobieta spełnia w życiu rodzinnym. Nie można też zapomnieć o poważnym zadaniu, jakie spełniają kobiety w ramach całego Kościoła ${ }^{61}$.

Trzeba uwzględnić wszystkie postulaty wynikające $\mathrm{z}$ integralnego powołania rodziny. Konieczne jest zrewidowanie prawnej struktury społeczeństwa oraz prawidłowe usytuowanie funkcji władz państwowych. Rodzinna i wspólnotowa konstytucja ludzkości powinna odgrywać główną rolę w formułowaniu zasad ustrojowych oraz moralno-prawnej ocenie sytuacji społeczeństwa ${ }^{62}$.

56 Por. FC 28.

57 Por. Benedykt XVI, Enc. Deus caritas est, nr 10.

58 Por. J. Bajda, Powołanie małżeństwa..., dz. cyt., s. 151.

59 Por. J. Bajda, Powołanie małżeństwa..., dz. cyt., s. 152.

60 Por. Jan Paweł II, Adhort. Christifideles laici, nr 49.

61 Por. FC 20.

62 Por. J. Bajda, Powołanie małżeństwa..., dz. cyt., s. 152. 
Prawidłowy ład społeczny wymaga prawidłowego uformowania wszystkich ludzkich racji przez rodzinną konstytucjęludzkości, otrzymaną jako dar od Boga-Ojca, który sprawił, że ludzie są braćmi i siostrami w Chrystusie. Tego rodzaju reforma jest dziełem ściśle nadprzyrodzonym i w sposób ścisły łączy się z misją Ludu Bożego, który ma zadanie budować nową ludzkość. Dzieło to jest pastoralnym urzeczywistnianiem się Kościoła w świecie. Natomiast w procesie tym bardzo istotną i niezastąpioną funkcję spełnia właściwie uformowana rodzina chrześcijańska wyrastająca z sakramentu małżeństwa. ${ }^{63}$

Mężczyzna i kobieta będący naturalnymi filarami rozwoju rodziny i społeczeństwa bez wątpienia pozostają centrum przestrzeni, w której rozwija się człowieka jako obywatel w suwerennym państwie. Z tego też tytułu „społeczeństwo uznaje rodzinę za swoją instytucję. Oznacza to, że działa ona w jego imieniu i jego interesie, spełniając ważne zadania dla egzystencji społecznej”64.

\section{Zakończenie}

Budowanie społeczeństwa jako rodziny ludzkiej wydaje się istotnym aspektem rozwoju każdego państwa. Niezależnie bowiem od wszelkich analiz na poziomie mikro-, makro- czy mezosocjologicznym, rodzina pozostaje najcenniejszym jego ogniwem. Społeczeństwo bowiem jako rodzina ludzka to wspólnota struktury życia i miłości w funkcjonalnym państwie. Budowanie społeczeństwa bez określonej, dodajmy chrześcijańskiej wizji rodziny, odartej z praw moralnych i etycznych, prowadziłoby do dehumanizacji a nie rozwoju.

Jan Paweł II wyraźnie zaznacza: „Rodzina jest sanktuarium życia ludzkiego od narodzin aż po naturalny kres. Ojciec i matka są kolumnami tej świątyni, wzniesionej na fundamencie przymierza małżeńskiego i wierności Boga" ${ }^{\text {. }}$. W tym zakresie społeczeństwo będące organizmem egzystencji rodziny pozostaje „dobrem wspólnym” ich rozwoju. Tylko w tym przypadku można mówić o integralnym aspekcie korelacji, oddziaływania rodziny

63 Por. J. Bajda, Powołanie małżeństwa..., dz. cyt., s. 153.

64 W. Turnowiecki, Rodzina w polskiej polityce społecznej, w: Wprowadzenie do polityki społecznej, red. R. Gabryszak, D. Magierek, Warszawa 2009, s. 165-166.

65 Jan Paweł II, Misja chrześcijańskiej rodziny, w: Rodzino, co mówisz o sobie? Dokumenty i przemówienia papieskie w Roku Rodziny, red. A. Świerczek, Kraków, 1995, s. 386. 
na społeczeństwo. Trzeba dodać, że rodzina powstaje, rozwija się, wzrasta, dojrzewa i staje się dla człowieka gniazdem, również wspólnym gniazdem środowiska lokalnego, w którym społeczeństwo jest doczesnym miejscem realizacji jej zadań i celów. Wydaje się, że przywrócenie etycznego ładu w życiu jednostki i rodziny prowadzi do wizji społeczeństwa opartego na kanonie aksjologicznym, w którym każdy obywatel posiada właściwą podmiotowość.

Budowanie społeczeństwa jako rodziny ludzkiej jest dobrem wspólnym. Dobro wspólne, jak zauważa Jerzy Bajda, powinno być rozumiane personalistycznie, jako dobro, w którym „każda osoba tworząca rodzinę jest podmiotem i konkretnym wcieleniem tego dobra - wszystko bowiem dzieje się dla osoby, dla jej ostatecznej pełni, osiągalnej w zjednoczeniu z Bogiem"66, społeczeństwo zaś jest miejscem realizacji tego dobra.

66 J. Bajda, Rodzina miejscem Boga i człowieka, Łomianki 2005, s. 361. 